(C) 1982 ISIJ

\title{
焼結層内における水分凝縮現象とその層通気性 におよぼす影響
}

\author{
和島 正巴* $\cdot$ 細谷 陽三*·柴田 充蔵* \\ 相馬 英明*.田代＼cjkstart清*
}

\section{Condensing Phenomenon of Moisture in Sintering Bed and Its Effect on Bed Permeability}

\author{
Masami Wajima, Yozo Hosotani, Juzo Shibata, \\ Hideaki SomA, and Kiyoshi TASHIRO
}

Synopsis :

Condensing phenomenon of moisture in sintering bed and its effect on sintering process were quantitatively studied through a mathematical model and experiments with sintering pot. The results obtained are as follows :

(1) Remarkable reduction of bed permeability after ignition is mainly due to formation of moisture condensation zone in bed. Resistance to gas permeation in moisture condensation zone is higher than that in initial raw mixture zone.

(2) The amount of condensed moisture is determined by the difference between wet-bulb temperature of gas passing through the bed and temperature of raw mixture. The less the difference is, the less the amount of condensed moisture is.

(3) As the amount of condensed moisture reaches a critical level at which sticking force of fine grains in quasi-particles starts to decrease, quasi-particles begin to agglomerate. Thus voidage of bed decreases and resistance to gas permeation increases sharply.

(4) It is proposed that effective means for suppressing moisture condensation after ignition are increase of raw mixture temperature, reduction of humidity in gas passing through bed, addition of moisture-absorber to bed and granulation of raw mixture at lower moisture content, etc.

\section{1. 緒言}

焼結反応を效涪よく進行させ，かつ良好な品質の焼結 鉱を製造するには，焼結層内に適量の空気を流すことが 必要である. しかし多くの暘合，必要な通過空気量の確 保は，焼絬層の通父抵抗が大きいため必ずしも容易では ないのが現状である．近年，省エネルギー対策として， 高層厚化による歩留り向上, 燃料原単位低減が指向され つつあり，焼結層の通気性改善がますます重要な課題に なつてきている.

従来この層通父性を们上させる方策としては，原料の 事前処理を強化して，ストランド上の原料層の通気抵抗 を低減させようとする試みが多い。しかし一般に焼結過 程における層の通気抵抗は，点火する以前の原料層の通 気抵抗にくらべ著しく増大寸る，それにもかかわらず， その原因についての本格的な検討は，これまであまりな
されてきたとはいえず，若干の報告があるにすぎない1 $\sim$ ).

そこで著者らは，焼結過程において，通気抵抗が点火 後急速に増大する要因を調査し，さらに，その結果に基 ういて焼結層の通気性改善技術を検討した。

\section{2. 実験方法および実験内容}

\section{$2 \cdot 1$ 実験装置および実験条件}

実験に使用した焼結鍋試験装置の概要を Fig. 1 に示 す，試験鍋は，著者らの考案による壁側漏風を防止した サンドシール型試験 鍋 $\left.{ }^{14}\right)(255 \mathrm{~mm} \phi \times 400 \mathrm{~mm})$ である.

実験条件を Table 1 に示す. 基準条件に対して, 一 部，初期原料温度上昇実験では，配合原料をあらかじめ 均一に予熱し，点火前の配合原料温度が $30^{\circ} \mathrm{C}$ になるよ らにした．低水分造粒実験では，ベントナイトを $1 \%$ 添 加して初期含水率を $4.0 \%$ にした。実験に使用した配合 
原料の粒度構成を Table 2 に示す. 実験は特に断わり のない限り基準原料で行つたが，燒結初期の通過風量増 加の影響をみるため，粗粒化した原料についても一部実 験した．焼結鉱の成分は，いずれも $\mathrm{SiO}_{2}: 5.6 \%, \mathrm{Al}_{2} \mathrm{O}_{3}$ $: 2.0 \%, \mathrm{CaO} / \mathrm{SiO}_{2}: 1.3$ である.

\section{$2 \cdot 2$ 実機における対応確認試験}

鍋試験装置による実験結果と実操業との対応を見るた め, 実機で層表面通過風量预よび層内水分分布を測定し た，層表面通過風量は，焼結層表面に超音波風速計をの せてストランドとともに移動させ，排鉱部に至る通過風 量の経時変化を測定した。 また層内水分分布の測定は, 焼結機を停止して (ブロアーも停止), 焼結層表面から 掘り起こして試料を採取し，含水率を測定した。

\section{$2 \cdot 3$ 実験内容}

2.3.1 焼結過程の層表面通過風量分布測定

まず，鍋試験装置による実験および実機における焼結

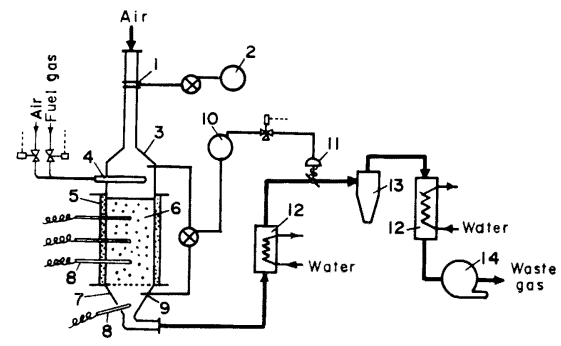
8. Thermocouple
9. Pressure elements
10. Pressure controller
11. Control valve
12. Cooler
13. Cyclone
14. Blower

6. Raw mixtur

Fig. 1. Apparatus for sintering experiments.

Table 1. Experimental Conditions.

\begin{tabular}{|c|c|c|}
\hline Item & & Value \\
\hline Raw mixture weight & $\mathrm{kg}$ & 40 \\
\hline \multirow{2}{*}{ Mixing time $\left\{\begin{array}{l}\text { Primary } \\
\text { Secondary }\end{array}\right.$} & $\min$ & 2 \\
\hline & $\min$ & 5 \\
\hline Ignition time & $\min$ & 1.5 \\
\hline Bed height & $\mathrm{mm}$ & 400 \\
\hline Suction pressure & $\mathrm{mm} \mathrm{H}_{2} \mathrm{O}$ & 1500 \\
\hline Initial moisture content & wt $\%$ & $6.0(4.0)$ \\
\hline Coke in mixture & wt $\%$ & 3.8 \\
\hline Initial raw mixture temperature & ${ }^{\circ} \mathrm{C}$ & $10(30)$ \\
\hline
\end{tabular}

過程の層表面通過風量の分布を測定し，再者の対応を確 認した.

\section{$2 \cdot 3 \cdot 2$ 焼結層内の圧力損失測定}

次いで，焼結過程における層通気抵抗支邽要因を明ら かにするため，層内の压力分布を測定した．測定は試験 鍋側壁より高さ方向に $50 \mathrm{~mm}$ 間隔で, 熱電対 (外径 8 $\mathrm{mm} \times$ 内径 $6 \mathrm{~mm}$ 磁製保護管, 素線 $\mathrm{Pt}-13 \% \mathrm{Rh}$ ) と圧 力検出端（ステンレス管，外径 $6 \mathrm{~mm} \times$ 内径 $4 \mathrm{~mm}$ ) を 鍋中心までそう入し，温度と生力の同時測定を行つた。 なお使用した熱電対は，あらかじめその灾答速度を測定 しておき，測温データを補正した。

\section{$2 \cdot 3 \cdot 3$ 層内水分分布の測定}

前項の層内压力損失の測定絬果より，下層に形成され る水分凝縮ゾーンの通気阻害がかなり著しいと推察され たので, 水分凝縮挙動を調査するため, 層内の水分分布 を測定した．鍋試験での測定は，試験鍋の側壁に設けた $25 \mathrm{~mm} \phi$ の原料サンプリング孔より，ブロアーを停止後 パイプを打ち込んで原料を採取し，含水率を測定した。 な持層内水分分布の測定は実機でも行つた。

\section{3. 実 験 結 果}

\section{1 焼結層表面通過風量分布}

鍋試験（1500 $\mathrm{mmH}_{2} \mathrm{O}$ 定差圧制御）と怣操業におけ る層表面通過風量の測定結果を Fig. 2 に示す。通過風 量は点火開始之同時に急激に低下し，その後わずかずつ 減少するが, 焼結後半では逆に增加する傾向が多られた。 特に, 焼結開始 1 2 min での風量低下が著しく, 点火

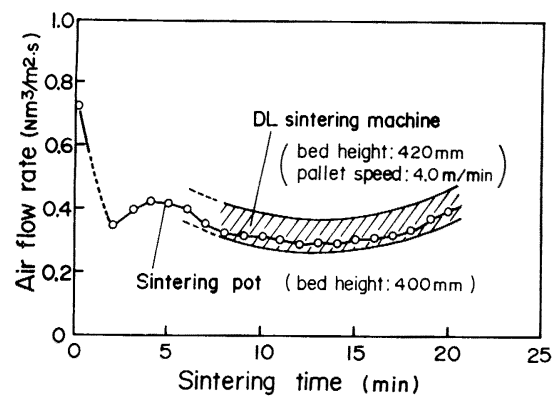

Fig. 2. Patterns of air flow during sintering at the sintering pot and the DL sintering machine (Grate area : $460 \mathrm{~m}^{2}$ ).

Table 2. Size distribution of raw mixture (wt $\%$ ).

\begin{tabular}{|c|c|c|c|c|c|c|c|c|}
\hline \multirow{2}{*}{ Raw mixture } & \multicolumn{7}{|c|}{ Size $(\mathrm{mm})$} & \multirow{2}{*}{$\begin{array}{c}\text { Mean size } \\
(\mathrm{mm})\end{array}$} \\
\hline & $10 \sim 5$ & $5 \sim 2$ & $2 \sim 1$ & $1 \sim 0.5$ & $0.5 \sim 0.25$ & $0.25 \sim 0.125$ & -0.125 & \\
\hline Basic mixture & 13.4 & 27.6 & 13.4 & 9.6 & 9.0 & 7. 2 & 19.8 & 2. 30 \\
\hline Coarser mixture & 17.9 & 34.8 & 15.2 & 11.0 & 7.6 & 5.0 & 8.5 & 2.92 \\
\hline
\end{tabular}




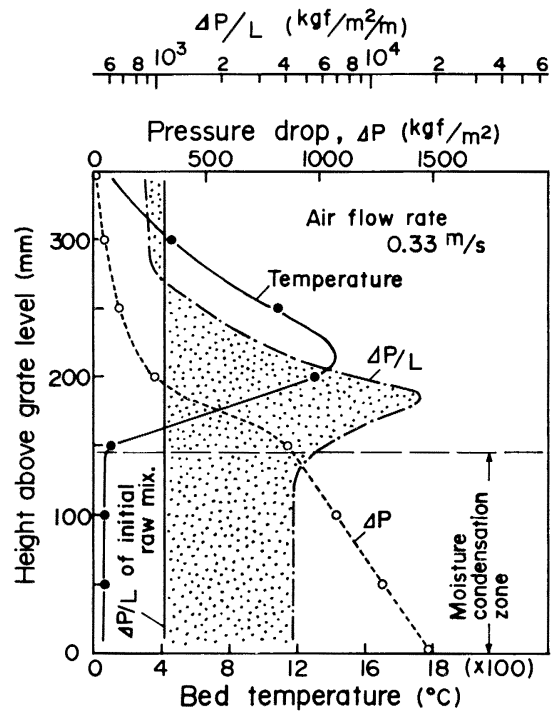

Fig. 3. Pressure drop in sintering bed at $8 \mathrm{~min}$ after ignition.

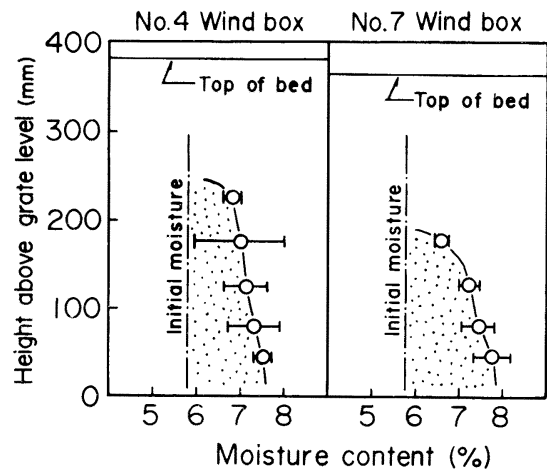

Fig. 4. Moisture condensation in sintering bed on the DL sintering machine (Grate area : $118 \mathrm{~m}^{2}$, Total wind boxes : 19)

前のそれの約 $1 / 2$ 程度に低トする.

\section{2 焼結層内の圧力損失}

Fig. 3 は鍋試験において，焼絬開始後 $8 \mathrm{~min}$ 時点の 焼結層内の温度分布および成力損失を測定した結果であ る. 単位高さ当たりの圧損 $(J P / L)$ が最も大きいの は, ヒートウェーブ前進側の約 $1000^{\circ} \mathrm{G}$ 付近の部分であ

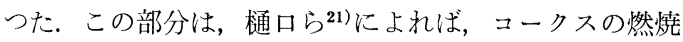
が最も急速に行われている部分にほぼ対応していること から，コークス燃焼ゾーンとみなせる．しかし，下層の 比較的低温領域（水分凝縮ゾーソ）の $A P / L$ も初期原 料にくらべて大きく，このゾーン幅が相対的に大きい焼 結過程前半では，水分凝緶ゾーンの通気抵抗が層全体の 通気抵抗を左右しているといえる。他方，水分凝縮ゾー
ン幅がしだいに減少し，高温ゾーン幅が抎大する焼結過 程後半では, 高温ゾーソの通気低下要因の比重が増して くると推論されるが, 初期の焼結進行を推定するために は水分凝縮挙動の解明が必要と考光られた.

\section{3 焼結層内における水分凝縮}

Fig. 4 に実操業に求ける焼結層内の水分凝縮量測定結 果を示す。他の研究者らが指摘するように ${ }^{8)}$ 13), 下層 部に水分凝縮ゾーンが存在することが確認された，その 水分量は，初期水分 $5.8 \%$ に対して 7 8\%と1〜2\% の凝縮量で，下層ほどその量はやや増加している傾向が みられた。 また水分凝縮ゾーンは，焼結初期のかなり早 い時期に形成されることが推察された.

\section{4. 焼結層内の水分挙動の解析}

\section{1 焼結層内の水分変化}

一般に，焼結原料層中では，約 $400 \mathrm{~mm}$ 程度のわずか な距離の間にコークスの燃焼反応や原料の溶融，再凝固 現象が生起しており，温度は常温から $1400^{\circ} \mathrm{C}$ 程度ま で分布している．層内を通過するガスもこの固体側の温 度に影響されて，層内各位置において大きな温度変化を 示すので，水分の凝縮もこのガス温度の変化の中で考慮 されなければならない。

たとえば，コークスの反応ゾーンを通過した後のガス は，高温度になつて下方に移動するが，皇だ反応を起こ していない層に熱を与えて加熱し，さらに下方の湿つた 原料層を通過する際には，その層を温めると同時に，存 在している水分を蒸発させるからガス中に多量の水蒸気 を含むことになる，しかし，この水蒸気も，さらに下方 へとガスが流れ温度低下していく際に，もはやガス中に 存在できなくなり, 再度固体側へと水分を凝縮させる結 果となる．このような通過ガスを介しての層上部から下 部への水分移動が，点火開始後の経過時間の中で非定常 的に起こつている.

ここに述べたような相互に関係する諸現象を明らかに するために, 從来の報告16)では含まれていない水分凝縮 過程について，今回新たに理論および実験的検討に基づ き，以下のようなモデル化を行い，解析を進めた。

\section{$4 \cdot 2$ 層内水分挙動の数式モデル}

\section{$4 \cdot 2 \cdot 1$ 基礎式}

焼結原料層内の層厚方向に，断面内では均一な微小部 分を考え，この部分におけるガス側エンタルピ収支をと ると, (1) 式が得られる.

$$
\begin{aligned}
& -G \frac{\partial\left(C_{\mathrm{g}} T_{\mathrm{g}}\right)}{\partial Z}-\frac{6(1-\varepsilon)}{d_{\mathrm{p}}} h_{\mathrm{p}}\left(T_{\mathrm{g}}-T_{\mathrm{s}}\right) \\
& =\varepsilon \rho_{\mathrm{g}} \frac{\partial\left(C_{\mathrm{g}} T_{\mathrm{g}}\right)}{\partial \theta} \ldots \ldots \ldots \ldots \ldots \ldots \ldots \ldots \ldots \ldots \ldots \ldots \ldots \ldots \ldots \ldots \ldots \ldots \ldots
\end{aligned}
$$


ここで，（1）式左辺のガス層内通過に基づく移動項, 粒 子流体間の熱交換項に対して, 右辺の原料層空隙部分に 基づくガス側の蓄積項は, 一般に非常に小さいので無視 することができる。したがつて，(1)式右辺をゼロとし て整理すると,

$$
\begin{gathered}
G\left(C_{\mathrm{p}}+C_{\mathrm{H}} H_{\mathrm{g}}\right) \frac{\partial T_{\mathrm{g}}}{\partial Z}+\frac{6(1-\varepsilon)}{d_{\mathrm{p}}} \\
h_{\mathrm{p}}\left(T_{\mathrm{g}}-T_{\mathrm{s}}\right)+R_{\mathrm{w}}^{*} C_{\mathrm{H}} T_{\mathrm{g}}=0
\end{gathered}
$$

となる. 一方, 固体原料側に関してのエンタルピ収支よ り，(3)式が導き出される.

$$
\begin{aligned}
& (1-\varepsilon) \rho_{\mathrm{S}}\left(C_{\mathrm{s}}+C_{\mathrm{w}} W_{\mathrm{s}}\right) \underset{\partial \theta}{\partial T_{\mathrm{s}}}-\frac{6(1-\varepsilon)}{d_{\mathrm{p}}} \\
& h_{\mathrm{p}}\left(T_{\mathrm{g}}-T_{\mathrm{s}}\right)+R_{\mathrm{w}}^{*}\left(\lambda_{\mathrm{s}}-C_{\mathrm{w}} T_{\mathrm{s}}\right)=0
\end{aligned}
$$

また，ガス側および固体側に関する水分マスバランス により，(4)，（5)式が導かれる.

$$
\begin{gathered}
G \frac{\partial H_{\mathrm{g}}}{\partial Z}=R_{\mathrm{w}}^{*} \cdots \cdots \ldots \\
-(1-\varepsilon) \rho_{\mathrm{s}}-\frac{\partial W_{\mathrm{S}}}{\partial \theta}=R_{\mathrm{w}}^{*}
\end{gathered}
$$

さて, $R_{\mathrm{w}}^{*}$ は含水率変化速度式で, 水分凝縮過程およ び乾燥過程に対して，おのおの次の形で表される.

（1）水分凝縮過程

水分の凝縮は, 原料層を高温のガスが通過して行く過 程でしだいに温度降下し，ガス中の湿度が飽和湿度に達 した段階で始まり，その湿度変化は 飽和湿度線図に従 う.ここで飽和湿度曲線は, 次式で表される。

$$
H_{\mathrm{g}, \mathrm{s}}=0.005 \exp \left(0.057 T_{\mathrm{g}}\right)
$$

水分凝縮過程は (6) 式で表される湿度と温度の関係を維 持しながら，ガス温度の低下に対応して湿度も変化する から，水分の変化速度は次式となる.

$$
\begin{aligned}
& R_{\mathrm{w}}^{*}=G \frac{\partial H_{\mathrm{g}}}{\partial Z}=G \cdot \frac{\partial H_{\mathrm{g}}}{\partial T_{\mathrm{g}}} \quad \partial T_{\mathrm{g}} \\
& =G \frac{\partial H_{\mathrm{g}, \mathrm{s}}}{\partial T_{\mathrm{g}}} \quad \frac{\partial T_{\mathrm{g}}}{\partial Z}
\end{aligned}
$$

ここで，凝縮したフリーの水分が，いかなる挙動を示す かが問題となる. 固体粒子周囲のガス境膜における水蒸 気拡散速度， $R_{\mathrm{w}}^{\prime}$ は次式で表せる.

$$
R_{\mathrm{w}}^{\prime}=\begin{array}{cc}
6(1-\varepsilon) & h_{\mathrm{p}} \\
d_{\mathrm{p}} & C_{\mathrm{p}}+C_{\mathrm{H}} H_{\mathrm{g}}
\end{array}\left(H_{\mathrm{s}}-H_{\mathrm{g}}\right)
$$

これから，ガス温度変化に対する水分拡散の相対速度を とると，(7)式の $\partial H_{\mathrm{g}, \mathrm{s}} / \partial T_{\mathrm{g}}$ とほぼ同等ないしそれ以 上のオーダーにあることから，凝縮水分の大半は固体側 に与えられるとみなせる。したがつて，（7)式を固体側 への水分凝縮速度式としてょいと考えられる.

（2）水分乾燥過程

乾燥過程については，鞭ら ${ }^{16)}$ の考光に基本的に従い，
恒率乾燥過程と減率乾燥過程を考虑する. 恒率期間では 水分の蒸発速度が速いために，ガスからの伝熱はすべて 水分の乾燥に用いられるので, 固体側の温度変化はない ものとしてよいから，(3)式第1 項をゼ口とすれば，次 式が得られる.

$$
R_{\mathrm{w}}^{*}=\begin{array}{ccc}
6(1-\varepsilon) & T_{\mathrm{g}}-T_{\mathrm{s}} \\
d_{\mathrm{p}} & h_{\mathrm{p}} & \lambda_{\mathrm{s}}-C_{\mathrm{w}} T_{\mathrm{s}}
\end{array}
$$

減率期間は, 鞭ら ${ }^{16)}$ と同样に求められる.

$$
R_{\mathrm{w}}^{*}=\begin{array}{cccc}
6(1-\varepsilon) & T_{\mathrm{g}}-T_{\mathrm{s}} & W_{\mathrm{s}}-w_{\mathrm{e}} \\
d_{\mathrm{p}} & h_{\mathrm{p}} & \lambda_{\mathrm{s}}-C_{\mathrm{w}} T_{\mathrm{s}} & w_{\mathrm{c}}-w_{\mathrm{e}}
\end{array}
$$

以上の展開による，(2)，(3)，(4)，(6)，(7)式 を用いれば，水分の凝縮過程が表現され，(7)式の代わ りに(8)式を適用すれば恒率乾燥過程が，(9)式を用い れば減率乾燥過程をとれぞれ表すことができる.

$4 \cdot 2 \cdot 2$ シミュレーション結果

前項の偏微分方程式で示される基礎式と, 鞭ら ${ }^{16)}$, 塚

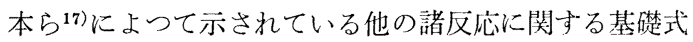

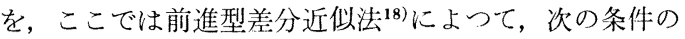
もとに数值積分を行つた，初期条件は，原料側の装入時 の状態として

$$
\theta=0, Z \geqq 0 ; T_{\mathrm{s}}=T_{\mathrm{s}_{0}}, W_{\mathrm{s}}=W_{\mathrm{s}_{0}}
$$

境界条件は，層最上部より流入するガ大側について，

$$
Z=0, \quad \theta>0 ; T_{\mathrm{g}}-T_{\mathrm{g}_{0}}, H_{\mathrm{g}}=H_{\mathrm{g}_{0}}
$$

として，おのおの与党られる.

Fig. 5, 6 にシミュレーション結果を示す. Fig. 5 は, 水分凝縮が, 焼結層内で併発的に起こつている各過 程と相対的にどのような関係になつているかを示したも のである．これから，下層部に水分凝維ゾーンが形成さ れ，焼結進行とともにヒートパターンの幅が挫大して行 く過程が認識できる.Fig. 6 は, 今回新たに提起した

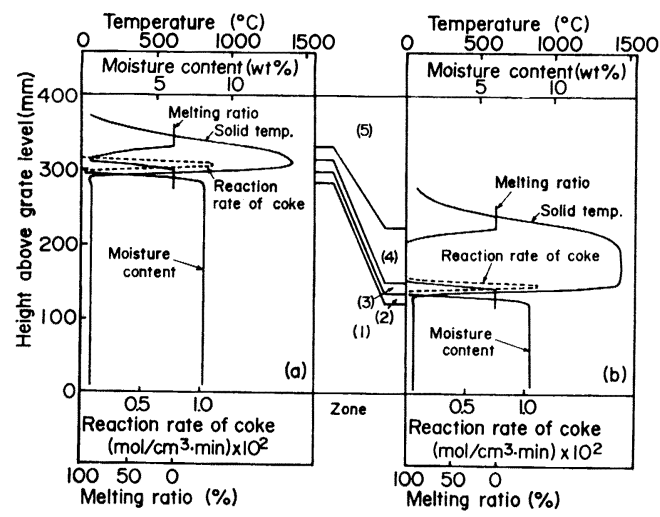

(1) Moisture condensation zone (2) Drying zone (3) Reaction zone (4) Melting zone (5) Cooling zone

Fig. 5. Relatives of each zone at $5 \mathrm{~min}$ (a) and $15 \mathrm{~min}$ (b) after ignition (Calculated for the Case 1 in Table 3). 


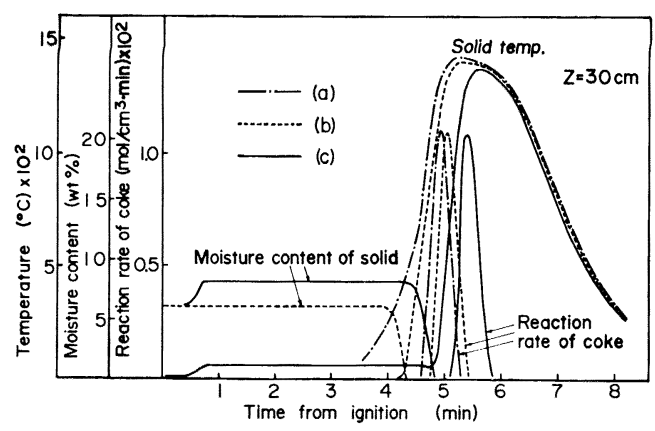

(a) Drying and condensing processes are neglected.

(b) Condensing process is neglected.

(c) Drying and condensing processes are considered.

Fig. 6. Effects of moisture condensation process on profiles of process variables (Calculated for the Case 1 in Table 3 ).

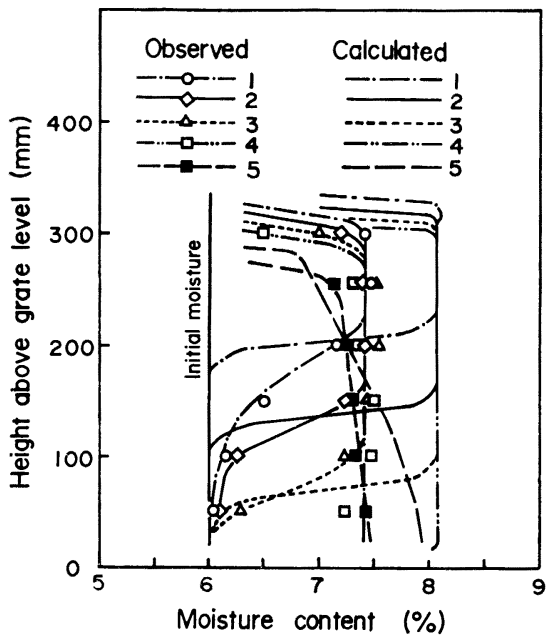

$1,2,3,4,5:$ At $30,45,60,80$ and 120 s after ignition respectively

Fig. 7. Comparison of calculated results with observed data of moisture condensation zone.

(Initial raw mixture temp. : $20^{\circ} \mathrm{C}$ )

水分凝維過程の影熋を明らかにするために, 従来, 鞭ら ${ }^{16)}$ により報告されている解析と対比した結果である。図 中の (a)は水分の乾燥, 凝縮過程をいつさい無視した 場合 ${ }^{21)}$ ，（b ) は乾燥過程のみを考慮した場合 $\left.{ }^{16)}, （ \mathrm{c}\right)$ は 水分凝縮過程までを考慮した場合であり，（a ）と（b)の 違いよりも，（c）の場合の方が顕著な差違が認められ る. 水分凝縮過程により, 明らかに原料層の水分蒸発完 了が遅れており，その結果として昇温開始および反応带 の形成が遅れ，かつ最高温度も低下している。 これらは 凝縮した水分の蒸発に，より多くの熱を必要とした結果 と推定される。

このように，水分凝維過程が，全体の焼結過程に著し
い影響をおよぼすことが明らかになつたので，以下凝縮 過程について,さらに詳細に検討する.

Fig. 7 は, 初期原料温度 $20^{\circ} \mathrm{C}$, 初期水分 $6.0 \%$, 通過風量 $0.33 \mathrm{Nm}^{3} / \mathrm{m}^{2} \cdot \mathrm{s}$ の条件に打ける水分凝縮ゾー ン形成過程を示した実測結果，計算結果である。なお， 計算結果は実測に基づく層収縮量で位置補正して示して ある．凝縮水分の絶対值は必ずしもよい一致を示してい ないが，下層への凝縮ゾーンの移動速度は，実測結果と ほぼ一致している. 凝縮水分值については, 点火期間 $(90 \mathrm{~s})$ を過ぎると実測值と計算值がしだいに一致してく るが，点火期間中でこのような不一致が生ずるのは，特 に急激な通気变化を示す点火時のシミュレーション精度 をさらに向上させる必要があることを示している.

以上，計算結果と実験結果の傾向が一致するので，こ れまで展開した考察は近似的解析として妥当なものと考 えられる.

\section{3 水分凝縮挙動}

以上の結果より，焼結層内での水分凝縮挙動は次のよ らに考えられる.

Fig. 8 は，凝縮ゾーン形成過程における固体とガス の変化を示した一例である，a）において，減率乾燥ゾ ーンの上端に達したガスは，このゾーンを通過する過程 で水分を蒸発させ，固体温度も上昇させて，みずからの

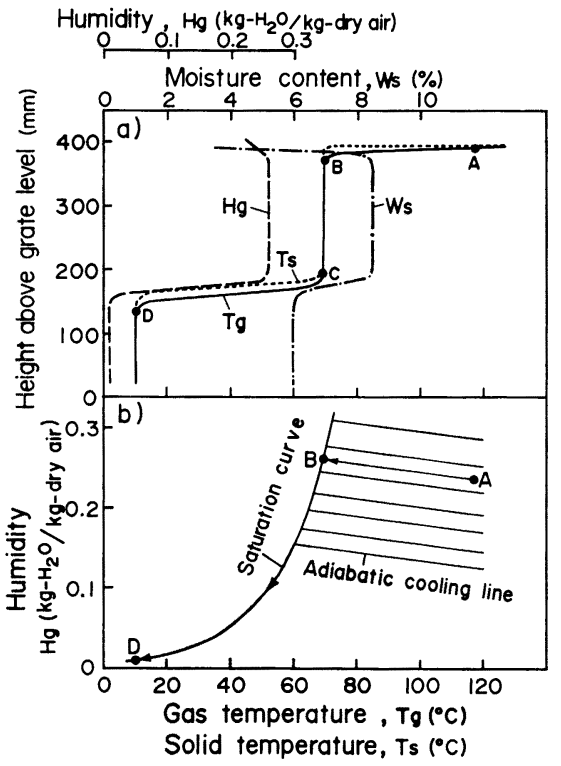

a) Sintering bed b) Humidity chart

Fig. 8. Relation between moisture content of solid $\left(W_{\mathrm{s}}\right)$, solid temperature $\left(T_{\mathrm{s}}\right)$, gas humidity $\left(H_{\mathrm{g}}\right)$ and gas temperature $\left(T_{\mathrm{g}}\right)$ in bed. $\mathrm{A} \sim \mathrm{D}$ shows breaking point on state of gas. 
温度は降下しつつ, 恒率乾燥ゾーンに達する, 恒率乾燥 ゾーン内では, ガス温度はさらに低下するが, 固体は湿 球温度まで予熱されており, 固体温度は変化せず, ガス からの伝熱はすべて水分蒸発に消費される.

この過程に利けるガス側の変化の軌跡を湿度図表上で 表せば， b ）のとおりとなる. ガスは A点から $\mathrm{B}$ 点汇向 かつて変化する.この変化は断熱冷却線汇沿う， B点の 温度は, 断熱飽和温度または湿球温度である。

a) で， B 点に達したガスは固体と等温なので, 水分 飽和状態のま層内を通過する。一方, 固体含水率は, $\mathrm{B}$ 点で蒸発が停止して以降, すでに㠜縮が平衡に達して いる状態のまま保持される.

$\mathrm{C}$ 点以降に, ガスの露点温度以下の低温固体が存在す る場合, $\mathrm{C}$ 点に達した飽和ガスは水分を凝縮しはじめる. 同時に, 固体温度は凝縮潜熱拉よびガスからの伝熱によ つて予熱され，a）に示すよらに， C 点〜D点にかけて 温度勾配が生じる.

$\mathrm{G}$ 点以降のガス側の変化をみると, ガスはすでに飽和 状態にあるから, 伝熱に上るガス温度低下にともなつ て, b ) の B 点より飽和曲線に沿つて, 固体の初期温度 であるD点に向かつて下降し, D点で平衡に達する。

次に, 水分凝縮ゾーンの固体含水率がぞのような要因 で決定されるかを考察する.

これまでの記述から明らかなよらに，凝縮による固体 含水率の增加は, 通過するガスの露点温度以下にある固 体が, 露点温度まで予熱される過程で生じる.しかし, 連続的にガスが供給される焼結層内では, 次々に予熱が 進行し, 結局全層が湿球温度になるまで継続する. 従つ て, 定常状態に達した段階では, 水分凝縮は固体が湿球 温度まで予熱される過程で生じるといえる。

固体はガスからの伝熱と凝縮潜熱の両者によつて子熱 されるが, いずれにしても, 水分凝縮量はこの予熱温度 幅によつて決定されると考光られる.

湿球温度は, 層内の恒率乾燥ゾーンに流入しょらとす るガスの温度と湿度によつて決定される. 湿球温度を左 右する主な要因としては, 次のものが挙げられる.

（1）焼結層に投入される水分. 例光ば，大気中の湿 分, 点火・保熱時の燃焼排ガス中水分など. これらの增 加はガス湿度を上昇させ, 湿球温度を高める.

（2）層内通過風量. 通過風量の増加はガスの湿度を 低下させて湿球温度を低める.

（3）初期原料水分. その低下は蒸発する水分の絶対 量を減らし，ガスの湿度を低下させて 湿球温度を低め る.

以上の考察から，水分凝縮を抑制する上で，ガスの湿
Table 3. Experimental conditions in each test case.

\begin{tabular}{|c|c|c|c|c|}
\hline Case & $\begin{array}{l}\text { Initial } \\
\text { moisture } \\
\text { content } \\
(\text { wt } \%)\end{array}$ & $\begin{array}{l}\text { Initial } \\
\text { raw mixture } \\
\text { temperature } \\
\left({ }^{\circ} \mathrm{C}\right)\end{array}$ & $\begin{array}{l}\text { Air frow } \\
\text { rate } \\
\left(\mathrm{Nm}^{3} / \mathrm{m}^{2} \cdot \mathrm{s}\right)\end{array}$ & Note \\
\hline 1 & 6.0 & 10 & 0.33 & Base \\
\hline 2 & 6.0 & 30 & 0.33 & $\begin{array}{l}\text { Raw mixture of higher } \\
\text { temperature }\end{array}$ \\
\hline 3 & 6. 0 & 10 & 0.49 & Coarser raw mixture \\
\hline 4 & 4. 0 & 10 & 0.33 & $\begin{array}{l}\text { Raw mixture of lower } \\
\text { moisture content }\end{array}$ \\
\hline
\end{tabular}

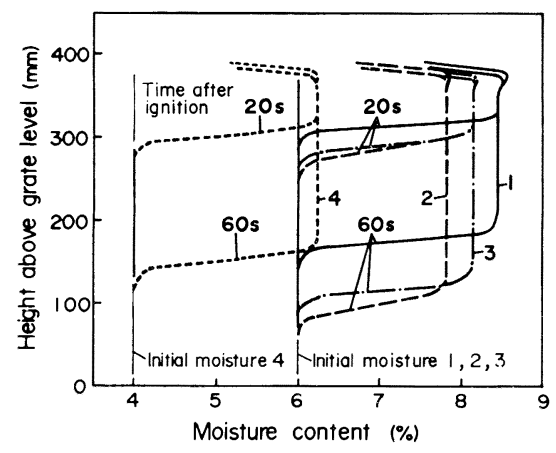

$1,2,3,4$ : Case No. in Table 3

Fig. 9. Calculated results of moisture condensation at various conditions.

度を低下させて湿球温度を低めるか，初期原料温度を高 めることが，有効であると推論される。

\section{4 水分凝縮挙動におよぼす操業条件の影響}

そこで,この推論をシミュレーションおよび瑪験で確 認した. 設定条件を Table 3 に示す.

Fig. 9 は, 点火開始後 $20 \mathrm{~s}, 60 \mathrm{~s}$ に打ける水分凝維 のシミュレーション結果である. Case 1 を基準にする と, Case 2 の初期原料温度を上梨させた場合, Case 3 の通過風量を增加させた場合に凝縮水分旱が低下した。 さらに, Case 4 の初期含水摔を低下させても, 若下凝 縮水分量が低下し, 水分凝縮が抑制されることが確諗さ れた。

Fig. 10 にシミュレーション絬果と咨験絬果を対比し て示すなな，計算結果は央測に基づく層收縮量で位崖 補正して示してある。これから,シミュレーション結果 と実験結果とは, 傾向が一致しており, これまでの考察 の妥当性が実験によつても確認された。

また，Fig. 11 はこの尖験において，(12)式年で整理 した水分凝縮ゾーンの通父抵抗係数 $\log f$ を示寸.

$$
\Delta P / L=f \cdot U_{\mathrm{m}^{1}}{ }^{1.3}
$$

水分凝縮ゾーンの通気抵抗は, 凝縮舅の減少にともなつ て低下寸る傾问にあることがわからた．なお， Case 3 の粗粒原料を用いた場合に，水分凝繀最に対して通気抵 


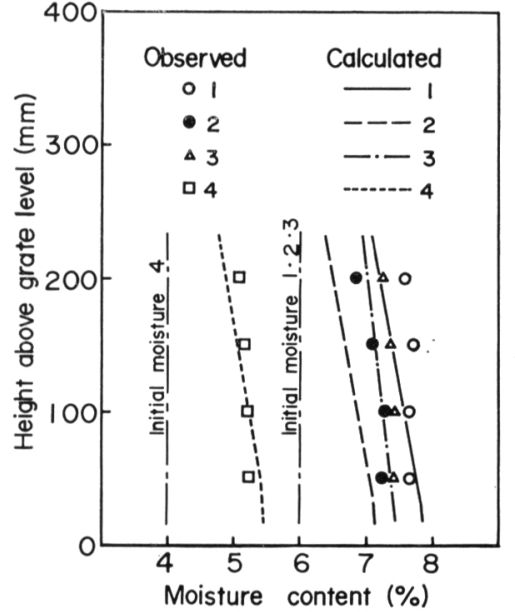

1, 2, 3, 4: Case No. in Table 3

Fig. 10. Comparison of calculated results with observed data of moisture condensation at 2.5 min after ignition.

抗が比較的小さいのは，微粉粒子量が少ないため，次に 述べる擬似粒子の崩壊程度が緩和された結果と考兄られ る.

\section{5 水分凝縮にともなう原料擬似粒子の崩壊}

水分凝縮に上る通気抵抗增大原因について，以下考察 する.

Photo. 1 に水分凝縮ゾーンからサンプリングした原 料の擬似粒子の状態を初期原料のそれと比較して示す. 水分の凝縮により, 擬似粒子の付着微粉部分の一部が流 し出されて合体している，このため層内の空隙率が減少 して通気抵抗が増加すると考光られる。これらの擬似粒 子挙動がなぜ生じるかについて，微粉焼結原料の粉体特 性を調査した。

一般に粉体の充填構造上の区分として，粒子と液体が 連続構造で, 空気が不連続に存在する状態 (Funicular2 域) から，さらに水分が増加して粒子間に空気が存在

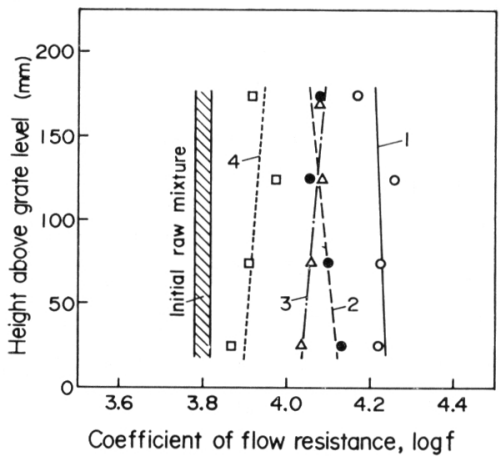

1, 2, 3, 4: Case No. in Table 3

Fig. 11. Observed data of flow resistance in moisture condensation zone.

Table 4. Plastic limits and liquid limits of raw materials $(<0.125 \mathrm{~mm})$.

\begin{tabular}{|c|c|c|c|}
\hline Description & Main mineral & $\begin{array}{l}\text { Plastic Limit, } \\
\% \text { (vs. solid) }\end{array}$ & $\begin{array}{l}\text { Liquid Limit, } \\
\% \text { (vs. solid) }\end{array}$ \\
\hline C. V. Rio Doce & Specularite & 8.8 & 13. 0 \\
\hline $\begin{array}{l}\text { Goldsworthy } \\
\text { Miferma } \\
\text { Bailadila }\end{array}$ & Hematite & $\begin{array}{l}12.0 \\
14.2 \\
16.8\end{array}$ & $\begin{array}{l}18.5 \\
16.0 \\
21.2\end{array}$ \\
\hline $\begin{array}{l}\text { Timblo } \\
\text { Salgaoncar }\end{array}$ & $\begin{array}{l}\text { Limonitic } \\
\text { hematite }\end{array}$ & $\begin{array}{l}18.8 \\
15.2\end{array}$ & $\begin{array}{l}22.0 \\
16.7\end{array}$ \\
\hline $\begin{array}{l}\text { Marcona } \\
\text { Tasu }\end{array}$ & Magnetite & $\begin{array}{l}12.0 \\
11.4\end{array}$ & $\begin{array}{l}13.4 \\
12.1\end{array}$ \\
\hline $\begin{array}{l}\text { Mill scale } \\
\text { Limestone } \\
\text { Return fine } \\
\text { Coke breeze }\end{array}$ & & $\begin{array}{l}17.4 \\
15.3 \\
20.3 \\
29.5\end{array}$ & $\begin{array}{l}\text { 18. } 3 \\
20.8 \\
22.1 \\
35.9\end{array}$ \\
\hline \multicolumn{2}{|c|}{ Average } & 16.0 & 19. 2 \\
\hline
\end{tabular}

しなくなる Capillary 域に移行する点を可塑限界 (P. L.）と称し，次いで水分が増加して流動しはじめる点を 液化限界 (L.L.) と呼んでいる19).

焼結原料は，粗粒子のまわりに微粉粒子が付着してお り，粘土などと異なり表面が不活性なので，P．Ｌ．以上 の水分量になると可塑性を帯び，ベッドを通過する排が 大の圧力で変形することが予想される．さらに L. L. 以上になると，重力により流動化すると考えられる.

そこで, JIS 法により焼結原料の P. L., L. L.を測
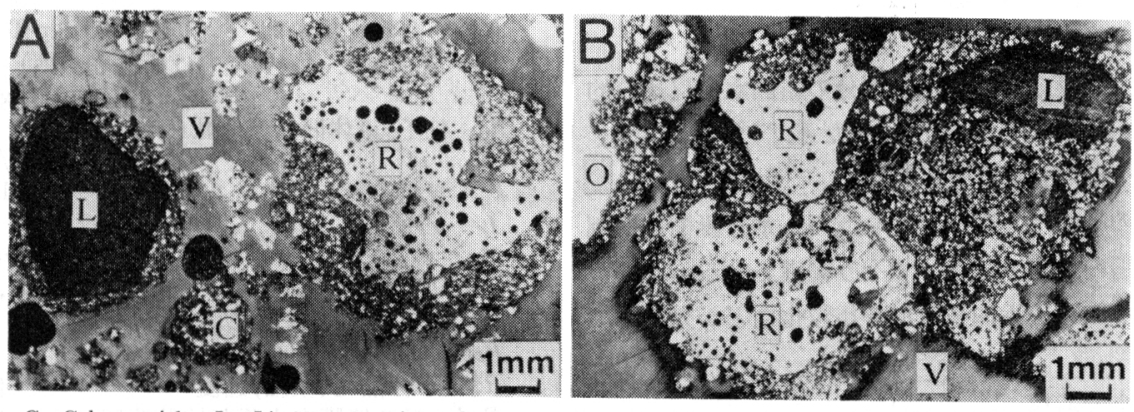

C: Coke particle L : Limestone particle O : Ore particle R: Sinter return particle V: Void (Resin)

Photo. 1. State of quasi-particles (A : Initial raw mixture, B : Raw mixture after moisture condensation). 
定した。 その結果を Table 4 に示す.コークスを除い て, P. L. は 9 20\% (vs. solid), L. L.は 12 22\% (vs. solid) 程度であり, 配合率によつても変わるが，こ れらを平均すると，P.L. $=16 \%$ (vs. solid), L.L. = 19 $\%$ (vs. solid) になる.

水分凝縮ゾーンの含水率は $8 \%$ 前後の值になる例が みられた. ここで, 粗粒子のまわりに付着している微粉 部分のみに水分が含まれていると仮定すると，上記微粉 量が $50 \%$ 以下の場合には，微粉部分の 水分量は $18 \%$ (vs. solid) にもなる. 水分の偏析などを考慮すると，さ らに高水分な部分の存在も考えられ，水分凝縮ゾーンで は配合原料の流動および合体などが十分起こり得るもの と推論される.

通常，よく経験されるように，焼結層が点火中に急激 に収縮するのは，水分凝縮によつて配合原料の流動およ び合体などが起こり，層空隙率が減少するためと考えら れる. このことは焼結鉱の品質にとつても重要な意味を もつ. 水分凝縮を抑制すれば, 層の収縮が減少し, 焼結 鉱の気孔率が増加して焼結鉱の被還元性，高温軟化溶融 性状が改善されるからである20).

また，このような機構で擬似粒子が崩壊するとすれ ば，初期水分が少ない場合，それだけ崩壊しにくいこと も明らかである. Fig. 11 に示すように, Case 4 の低 水分造粒に打いて最も通気抵抗が小さいのは，凝縮によ る水分増加量といらょり, 水分の絶対量が問題であるこ とを示しており，これまでの考察の妥当性を示唆するも のと考えられる.

\section{5. 焼結層の通気性を改善する 2,3 の 技術の提言}

ここでは, 水分凝縮ゾーンの通気抵抗を低減して, 焼 結過程前半の通気性を改善する技術を挙げる.

(1) 配合原料温度の上昇

返鉱温度の上昇，ミキサーへの蒸気吹き込み，ミキサ 一への温水添加, 生石灰添加など.

（2）水分吸収剂の添加

生石灰の水和反応による過剰水分の結晶水化（比較的 反応性の低い生石灰を使用する・）など.

(3) 点火前の初期通気度改善

初期通気の改善は, 湿球温度を低め, 水分凝縮を抑制 して，焼結層の通気改善をいつそら促進させる，そのた めには, バインダー添加や原料の粗粒化などが効果的で ある.

\section{（4）低水分造粒}

低水分化を指向した造粒技術の適用.
（5）点火炉・保熱炉でのコークス炉ガス，重油など の使用量低減による水蒸気発生量の減少

点火効率の向上や熱風排熱回収などにより，含水蒸気 燃焼排ガス量を減らし，点火・保熱期間における層通過 ガスの湿度を低下させる。

\section{6. 結言}

焼結層の通気性向上を目的として，層内通気抵抗の変 化, 層内下部に形成される水分凝縮ゾーンの形成機構, 通気性を改善する因子などについて検討した。

（1）水分凝縮ゾーンの通気抵抗は，初期原料のそれ より著しく大さい，凝縮ゾーンの形成速度は速く，短時 間内に最下層まで達する，焼結層通気性が，点火開始後 急速に低下するのは，水分凝縮ゾーンの形成が主な原因 である。

（2）水分凝縮量は，層内を通過するガスの湿球温度 と配合原料温度の差で主に決まり，温度差が少なければ 凝縮量は少ない。ガスの湿球温度は, 焼結層内にあつて は通過するガスの湿度によつて決まるので，ガスの湿度 を低下させるか, 原料温度を上昇させることが, 水分凝 縮を抑制することになる。

（3）水分凝縮ゾーンの通気抵抗が増大する原因は, 擬似粒子の微粉粒子間に存在する水分が過剩になり, 微 粉粒子が流動・合休し，層空隙摔が減少するためと考光 られる. したがつて水分凝縮の抑制は, 焼結層の通気性. 向上に有効であるばかりか，適度な気孔率を有する被還 元性の良好な焼結鉱を得るためにも非常に有効である.

\section{記号}

$C_{\mathrm{H}}, C_{\mathrm{w}}$ : 水蒸気, 水の比熱

$C_{\mathrm{g}}, C_{\mathrm{p}}:$ ガス比熱

$\left[\mathrm{kcal} / \mathrm{kg} \cdot{ }^{\circ} \mathrm{C}\right]$ $\left[\mathrm{kcal} / \mathrm{kg} \cdot{ }^{\circ} \mathrm{C}\right]$,

$C_{\mathrm{S}}$ : 配合原料比熱

$d_{\mathrm{p}}$ : 配合原料粒子径

$f:$ 通気抵抗係数

$G$ : 通過空気質量速度

$H_{\mathrm{g}}, H_{\mathrm{g} 0}$ : 空気湿度, 初期空気湿度 $\left[\mathrm{kcal} / \mathrm{kg}(\mathrm{dry}) \cdot{ }^{\circ} \mathrm{C}\right]$

$\left[\mathrm{kcal} / \mathrm{kg}(\right.$ dry $\left.) \cdot{ }^{\circ} \mathrm{C}\right]$

$$
\left(=\Delta P / L / U_{\mathrm{m}}{ }^{1.3}\right)
$$

$\left[\mathrm{kg}(\mathrm{dry}) / \mathrm{m}^{2} \cdot \mathrm{h}\right]$
$\left[\mathrm{kg}\left(\mathrm{H}_{2} \mathrm{O}\right) / \mathrm{kg}\right.$ (dry air) $]$

$H_{\mathrm{g}, \mathrm{s}}$ ：飽和湿度曲線 $\quad\left(=0.005 \exp \left(0.057 \cdot T_{\mathrm{g}}\right)\right)$

$H_{\mathrm{s}}$ : 空気湿度 $\left(T_{\mathrm{s}}{ }^{\circ} \mathrm{C}\right.$ に打外飽和湿度 $)$

$\left[\mathrm{kg}\left(\mathrm{H}_{2} \mathrm{O}\right) / \mathrm{kg}(\right.$ dry air $\left.)\right]$

$h_{\mathrm{p}}$ : 粒子-流体間伝熱係数 $\left(=k_{\mathrm{g}} \cdot \mathrm{Nu} / d_{\mathrm{p}}\right)$

$k_{\mathrm{g}}$ : 空気の熱伝導度 $\quad\left[\mathrm{kcal} / \mathrm{m} \cdot \mathrm{h} \cdot{ }^{\circ} \mathrm{C}\right]$

$L$ : ゾーン長さ [m]

$N u:$ ヌッセルト数 $\left(=2.0+0.6 \operatorname{Rep}^{1 / 2} \cdot \mathrm{Pr}^{1 / 3}\right) \quad[-]$

$\Delta P$ : 压力損失 $\left[\mathrm{mm} \mathrm{H}_{2} \mathrm{O}\right],\left[\mathrm{kgf} / \mathrm{m}^{2}\right]$

$\operatorname{Pr}:$ プラントル数 $\left(=C_{\mathrm{p}} \cdot \mu_{\mathrm{g}} / k_{\mathrm{g}}\right) \quad[-]$

$R e p:$ 粒子レイノルズ数 $\left(=d_{\mathrm{p}} \cdot G / \mu_{\mathrm{g}}\right) \quad[-]$

$R_{\mathrm{w}}^{*}:$ 水分蒸発 (凝縮) 速度

$\left[\mathrm{kg} / \mathrm{m}^{3} \cdot \mathrm{h}\right]$

$R_{\mathrm{W}}{ }^{\prime}$ : ガス境膜内水蒸気拡散速度

$T_{\mathrm{g}}, T_{\mathrm{g}_{0}}$ : ガス温度, 初期ガス温度

$\left[\mathrm{kg} / \mathrm{m}^{3} \cdot \mathrm{h}\right]$

$\left[{ }^{\circ} \mathrm{C}\right.$ ] 


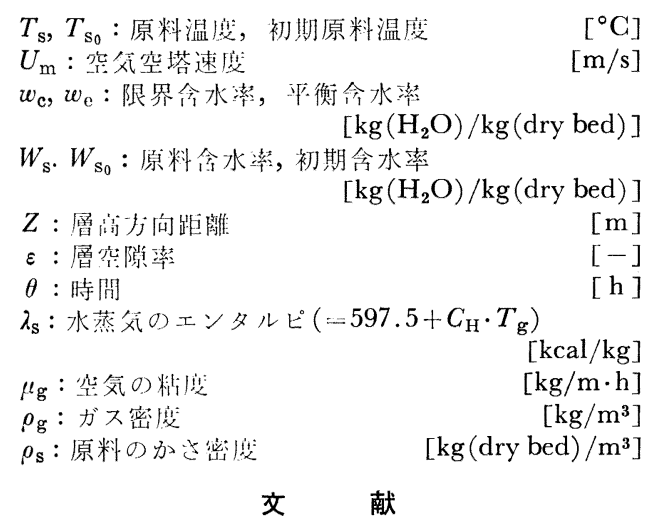

\section{文献}

1) E. $W$. Voice, $S . H$. Brooks, $W$. Davies, and B. L. Robertson: JISI, 175 (1953), p. 97

2) D. W. Mitchell: JISI, 198 (1961), p. 358

3 ) $M$. Boucraut and $R$. Rochas: Rev. Mét., 65 (1968) 12, p. 835

4) V.P. Puzanov and V.I. Korotich: Izv. VUZov, Cher. Met., (1966) 6, p. 58

5) V.I. Korotich and V.P. Puzanov: Steel in USSR, (1967) 7, p. 550

6) P. N. Grekov, S. I. Ryzhkov, L. I. Kaplun, and V.I. Korotich: Izv. VUZov, Cher. Met., (1975) 10, p. 34

7) A. N. Pokhvisnev et al.: Izv. VUZov, Cher. Met., (1976) 5, p. 26 (Trans. in English, British Industrial \& Scientific International Trans- lation Service)

8 ) R. Wild and K. G. Dixon: Agglomeration ed. by $W . A$. Knepper (1962), p. 565 [Interscience Publishers]

9) $V . I$. Korotich and $V . P$. Puzanov: Izv. VUZov, Cher. Met., (1965) 4, p. 53

10) M. Kowalewski: Prace Inst. Hutn., 22 (1970) 1, p. 3 (Trans. in English, British Iron and Steel Industry Translation Service)

11) $G . I$. Rudovskil, $A . A$. Kharitonov, and $G . I$. Serebrynik: Metallurg, (1971) 12, p. 7

12) G. I. Rudovskil, A. A. Kharitonov, G. $I$. Serebrynik, and $V$. F. Avdeev: Metallurg, (1973) 10, p. 11

13) V. G. Kotov and V.A. Shurkhal: Steel in USSR (1973) 10, p. 800

14）田代 清, 相馬英明, 細谷陽三, 和島正巳: 学振 54委-No. 1451 (昭和 53 年 7 月)

15）田代 清, 相馬英明, 和島正已: 未発表

16）鞭巌，樋口充蔵：鉄と鋼，56(1970) 3, p. 371

17）塚本 孝, 嶋田駿作, 田口敏夫, 柕口充蔵：鉄と 鋼, 56 (1970) 5, p. 661

18) L. LApidus: Digital Computation for Chemical Engineers, (1962), p. 131 [McGraw-Hill]

19）久保輝一郎，水渡英二，中川有三，早川宗八郎 共編：粉体（理論と忘用）(1962)，p. 501 [丸善]

20) 高田司, 相馬英明, 田代 清：鉄と鋼，64 (1978) 11, S 540

21）桶口充蔵，鞭嚴：鉄と鋼，53（1967）11, p. 1171 